\title{
A desesperada (in)ternura da noite e a impossibilidade de amar em Os Cus de Judas, de António Lobo Antunes
}

Natasha Gonçalves Otsuka

UFRJ

\section{Resumo}

O presente artigo discute os conceitos blanchotianos de noite - primeira noite e outra noite - e a caracterização do aspecto noturno na narrativa $O s$ Cus de Judas, do escritor português António Lobo Antunes. O protagonista narra seu percurso por Lisboa em uma noite ao lado de uma interlocutora. A noite na obra guarda não somente o espaço do discurso, mas também estabelece uma significação com o próprio estado do personagem. Além das consideraçóes sobre a noite, foram apresentados nesse artigo os conceitos de sono e de morte do teórico francês Maurice Blanchot como uma forma de complementar a análise do romance.

Palavras-chave: António Lobo Antunes; noite; Maurice Blanchot; Os Cus de Judas.

\section{Resumen}

Este artículo discute los conceptos blanchotianos de noche-primera noche y otra noche- y la caracterización del aspecto nocturno de la narrativa $O s$ cus de Judas, del escritor portugués António Lobo Antunes. El protagonista narra su viaje a través de Lisboa, en una noche, junto a una interlocutora. La noche en la obra guarda no sólo el espacio del discurso, sino que también establece sentidos en relación con el carácter del propio personaje. Además de las consideraciones sobre la noche, se presentan en este artículo los conceptos de sueño y muerte del teórico francés Maurice Blanchot, como una forma de complementar el análisis de la novela.

Palabras clave: António Lobo Antunes; noche; Maurice Blanchot; Os Cus de Judas. 
1. De acordo com o Dicionário de Narratologia, de Carlos Reis e Ana Cristina Lopes, o narrador autodiegético seria o aquele que "relata as suas próprias experiências como personagem central da história”, p. 251.

2. BLANCHOT, Maurice.

O livro por vir, 2005, p. 324.

3. Cf. HUTCHEON, Linda. Poética do pós-modernismo, 1991.
A noite, a essência da noite, não nos deixa dormir. Maurice Blanchot

A verdadeira aventura que proponho é aquela que o narrador e o leitor fazem em conjunto ao negrume do inconsciente, d̀ raiz da natureza humana.

António Lobo Antunes

Os Cus de Judas, lançado em 1979 em Portugal, é o segundo livro do escritor português António Lobo Antunes. Narrado em primeira pessoa, o personagem-narrador é um médico português, ex-combatente na guerra colonial em Angola, que estabelece um diálogo com uma interlocutora não identificada ao longo da duração de uma noite, inicialmente, em um bar em Lisboa e, posteriormente, no apartamento do personagem. A voz da interlocutora não é expressa diretamente durante o relato, o leitor só tem acesso ao discurso do narrador. Tal estratégia denota um indício de solidão extrema e da incomunicabilidade do personagem. Ao dialogar com essa figura anônima e destituída de voz, a narrativa aponta também para uma indeterminação acerca do seu interlocutor, que confere uma aproximação entre narrador e o futuro leitor do relato. Sendo assim, o narrador autodiegético ${ }^{1}$ introduz o leitor em seu plano narrativo. O leitor é o convidado a escutar o relato, tomar um uísque, fazer companhia ao narrador e, ao amanhecer, partir por Lisboa.

A associação entre o relato antuniano e o ato confessional é inevitável. Sobre a literatura da época, Blanchot afirma:

Não são coisas simples. A tentação que a literatura atual sente, de se aproximar cada vez mais do murmúrio solitário, está ligada a muitas causas, características do nosso tempo, da história, do próprio movimento da arte, e tem por efeito fazer-nos quase ouvir, em todas as grandes obras modernas, o que estaríamos expostos a ouvir se, de repente, não houvesse mais arte nem literatura. É por isso que essas obras são únicas, e por isso também que elas nos parecem perigosas, pois nasceram imediatamente do perigo e mal o controlam. ${ }^{2}$

Nota-se, na narrativa de Lobo Antunes, uma sintonia com a gênese do romance pós-moderno ${ }^{3}$ postulada pelo pensador francês. O discurso isolado do narrador, seu murmúrio solitário, parte de um momento da história da sociedade portuguesa: um regime ditatorial, as guerras de independência das colônias além-mar, o recrutamento forçado de jovens portugueses para o combate. A revisitação desse passado não tão distante questiona, redimensiona, oferece uma nova perspectiva da história. Para a teórica canadense Linda Huchteon, a ficção pós-moderna: "sugere [que] reescrever ou reapresentar o passado na ficção e na 
história é - em ambos os casos - revelá-lo ao presente, impedi-lo de ser conclusivo e teleológico." ${ }^{4}$.

O estopim da narrativa é a passagem por essa guerra inútil, na década de 1970, que mutilou física e psicologicamente uma geração de jovens portugueses. É a partir desse "perigo" que nasce o relato d'Os Cus de Judas.

Somado ao plano narrativo da permanência em solo africano, há dois outros que se intercalam: a rememoração da infância/juventude familiar e o plano do bar/apartamento. É pela memória que os diferentes tempos se interpóem, numa estrutura complexa, permeada de imagens e de metáforas, com longos períodos, em uma sintaxe particular na qual há uma simultaneidade cronológica entre passado e presente. A ruptura com uma sintaxe tradicional demonstra a transgressão, a insubordinação aos aspectos vigentes. Sobre essa questão, Gumercinda Gonda realiza a seguinte observação em sua dissertação de 1988, intitulada "O Santuário de Judas: Portugal entre a Existência e a Linguagem":

Haverá o predomínio do discurso do narrador, tendo como contraponto outros discursos que se chocam e entrecruzam. Por meio do grotesco e da paródia, surge a crítica ao social. Por isso mesmo, a linguagem, ocupa o espaço da transgressão, que é, a um só tempo, a ruptura e um instrumento de combate ao poder. Num certo sentido, pode-se dizer que a transgressão transforma-se numa das marcas de nossa época. ${ }^{5}$

O desespero e a incapacidade de superar os horrores da guerra são metamorfoseados na e pela linguagem. Os longos parágrafos descritivos, a ausência de diálogos e de pontuação imprimem o caráter de angústia do personagem, conforme observou Gonda: "A força que adquire a narrativa transborda na emoção com que Lobo Antunes, com grandes parágrafos, com raras pausas de pontuação, nos dá a exata dimensão do seu desespero que, resgatado pela memória, nos chega como que no instante da ação." ${ }^{6}$

Ainda sobre a estrutura do livro, cabe destacar a organização dos nomes dos capítulos seguindo a estrutura do alfabeto (de A a Z), indicando um percurso educativo, de instrução, tal como a alusão desejada pela tia para que o personagem se transformasse em um homem pela passagem da guerra/tropa: "Felizmente que a tropa há de torná-lo um homem ${ }^{7 ”}$. A experiência da guerra, no entanto, só é capaz de ensinar a mudez, a agonia, a impossibilidade de comunicação, a eterna noite.

A noite comporta na narrativa não apenas o dado temporal, de passagem de tempo, mas também constrói o espaço emocional em que o personagem vive e sob o qual ele não consegue
4. Ibidem, p. 147.

5. GONDA, Gumercinda. $O$ Santuário de Judas: Portugal entre a Existência e a Linguagem, 1988, p. 52.

6. Ibidem, p. 90 .

7. ANTUNES, António Lobo. Os cus de Judas, 2010, p. 15. 
8. SEIXO, Maria Alzira (org.).

Dicionário da Obra de Lobo Antunes, 2008, p. 437. Verbete de autoria de Maria Fernanda Afonso.

9. ANTUNES, António Lobo. Os Cus de Judas, 2010, p. 150. emergir. A temática da noite é constante na obra de Lobo Antunes. Segundo o Dicionário da Obra de Lobo Antunes, "a noite parece ser uma das opçóes temáticas obsessivas na escrita do au-

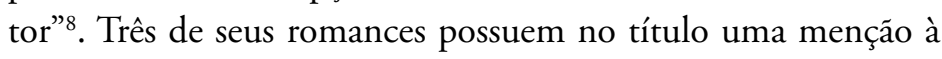
noite, direta ou indiretamente: Não entres tão depressa nessa noite escura (2000), O arquipélago da insônia (2008) e Não é meia noite quem quer (2012). Além desses romances, várias crônicas possuem títulos relativos ao aspecto noturno, tais como: Esta noite não estou para ninguém, Tratado dos crepúsculos, Crônica para não ler à noite e Não entres por enquanto nessa noite escura, variação do romance citado, publicado em 2000.

A análise empreendida focalizará o papel da noite e a dicotomia noite/manhã no romance $O s C u s$ de Judas e sua relação com a guerra, tendo como referencial teórico Maurice Blanchot e seu livro $O$ espaço literário. $\mathrm{Na}$ obra, o filósofo aborda o tema da noite em dois artigos: "O lado de fora", "A Noite" e "O sono, a noite". Segundo Blanchot, a noite possui duas formas distintas de manifestação: uma noite acolhedora onde o repouso é possível e a outra noite, estado caracterizado pela impossibilidade do adormecer, onde a angústia e a insegurança são abrigadas. A partir dessa distinçáo proposta por Blanchot, o presente trabalho irá analisar a "eterna noite" transcorrida em Os Cus de Judas. Serão utilizados como aparato teórico os estudos das seguintes professoras: Ângela Beatriz de Carvalho Faria, Gumercinda Gonda, Maria Alzira Seixo e Margarida Calafate Ribeiro.

\section{“Na completa noite escura que antecede o dia" 9}

Antes de empreendermos uma análise sobre o romance, convém ressaltar as possíveis acepçôes do vocábulo "noite". De acordo com o Dicionário Houaiss da Lingua Portuguesa, o vocábulo "noite" apresenta as seguintes definiçóes:

1. Tempo que transcorre entre o ocaso e o nascer do sol, em determinado lugar da Terra, de outro planeta ou de um satélite.

2. Horário em que está escuro por falta de luz solar, e em que geralmente as pessoas descansam ou dormem.

3. Ausência de claridade, escuridão, trevas.

4. Estado de dor, desesperança; tristeza, melancolia, abatimento.

5. Falta da visão, cegueira. 
Já o Dicionário de Símbolos, de Jean Chevalier e Alain Gheerbrant, aponta algumas interpretações:

Para os gregos, a noite (nyx) era a filha do Caos e a mãe do Céu (Urano) e da Terra (Gaia). Ela engendrou também o sono e a morte, os sonhos e as angústias, a ternura e o engano. As noites eram frequentemente prolongadas segundo a vontade dos deuses, que paravam o Sol e a Lua, a fim de realizarem melhor as suas proezas. [...] A noite simboliza o tempo das gestaçóes, das germinaçôes, das conspiraçóes, que vão desabrochar em pleno dia como manifestação da vida. Ela é rica em todas as virtualidades da existência. Mas entrar na noite é voltar ao indeterminado, onde se misturam pesadelos e monstros, as ideias negras. Ela é a imagem do inconsciente e, no sono da noite, o inconsciente se libera. Como todo símbolo, a noite apresenta um duplo aspecto, o das trevas onde fermenta o vir a ser, e o da preparaçáo do dia, de onde brotará a luz do dia. ${ }^{10}$

Como exposto anteriormente, a interlocução entre os personagens ocorre na duração de uma noite. Dessa forma, inicialmente, fica visível a relação estabelecida com os sentidos dicionarizados e não metaforizados da noite, isto é, o tempo transcorrido até o ocaso ao nascer do sol e o horário com ausência de luz solar. No entanto, ao deslocar o foco narrativo para a guerra colonial, o narrador estabelece uma relação com os sentidos conotativos, expressos nas acepçōes 3 e 4 do dicionário, que se prolongará no seu retorno à pátria e estabelecerá com a noite uma dupla significação. A noite encerra o espaço do medo, da penúria, da degradação. Essa associação entre noite-morte-angústia é expressa também no vocábulo "noite" no Dicionário de Símbolos que, no entanto, pontua a noite como o lugar para o recomeço, para a preparação da vida. A manhã surge como uma possibilidade de integração à sociedade, ao mundo externo, mas "essa manhâ" não chega. Em contrapartida, como os deuses gregos, o narrador deseja prolongar a sua noite, transformando-a numa eterna noite.

A narrativa de trevas e não solar é uma das características da pós-modernidade. Os horrores da guerra - da guerra colonial, da Segunda Guerra Mundial e, principalmente, o Holocausto ou a Shoah ${ }^{11}$ - alteraram a capacidade humana de narrar. Após vivenciar tal barbárie, como relatar? Márcio Seligmann-Silva aponta, no texto "Reflexóes sobre a memória, a história e o esquecimento", o livro de Elie Wiesel, ganhador do Prêmio Nobel da Paz em 1986 e sobrevivente do campo de concentração em Auschwizt, intitulado Nuit. O livro foi realizado a partir da promessa que Elie Wiesel fizera na primeira noite no campo de concentração: "Jamais je n'oublierai cette nuit, la première nuit de camp qui a fait de ma vie une nuit longue et sept fois verrouillée"12. A memória da noite no campo de concentração foi o fator motivador
10. CHEVALIER, Jean \& GHEERBRANT, Alain. Dicionário de Símbolos, 1997, p. 639-640.

11. Termo utilizado pelo professor Márcio SeligmannSilva, no ensaio "Apresentação da questão: a literatura do trauma”, em História, memória, literatura: o testemunho na era das catástrofes, 2003, p. 57.

12. "Nunca me esquecerei dessa noite, a primeira noite do campo que fez da minha vida uma noite longa e sete vezes selada." SELIGMANN-SILVA, Márcio (org.). História, Memória, Literatura. O testemunho na Era das Catástrofes, 2003, p. 52. 
13. RIBEIRO, Margarida. Os Cus de Judas, de António Lobo Antunes: dos tristes trópicos à feira cabisbaixa, 2004, p. 289. Grifos nossos.

14. Os dois conceitos blanchotianos serão detalhados posteriormente.

15. BLANCHOT, Maurice. O espaço literário, 1987, p. 163.

16. Ibidem, p. 164. para a narração de suas memórias, relatadas dez anos após sua liberação do campo de concentração em Auschwitz. Lobo Antunes, assim como Elie Wisel, expõe a desumanidade, a violência e a angústia da experiência traumática da guerra.

Em Lobo Antunes, a experiência encaminhou o narrador para uma vida sem retorno, o trauma náo pode ser mais desfeito e sua vida nunca voltará a ser a mesma de antes. A única narração possível será a fragmentada, permeada por lacunas em que a vivência na guerra irá invadir sua vida de retornado. As imagens da guerra continuavam a acompanhá-lo no seu cotidiano por Lisboa, conforme aponta Margarida Calafate Ribeiro:

A excessiva e neurótica imagem da África, com os seus cheiros de morte e estropiamento, projecta-se em tudo, bloqueando o futuro. Está na casa, no amor, na cidade, em todo o mundo infiltrado pelos olhos do narrador-personagem que se constitui o centro do seu mundo labiríntico e assumidamente marginal, construído <contra a corrente> (Antunes, 1991: 156) e do qual o mundo <normal> se afasta deixando-lhe a <casa deserta $>$. Nela vive numa permanente <noite $>$, entre as memórias da guerra, as reinvençóes das mulheres nativas que teve como prostitutas, e dela <desiberna $>$ à noite para pelos copos e pelos bares procurar o conforto que sabe previamente frustrado para a sua dor. ${ }^{13}$

A noite que é impossibilidade do sono remete ao conceito blanchotiano de outra noite. De acordo com o teórico francês, o acolhimento que a noite proporciona é permitido apenas na primeira noite. A primeira noite seria um estágio em que o repouso é possível, do descanso, da inconsciência. A profundidade silenciosa da noite encobre os falares, as movimentaçôes. Esse é o estágio acolhedor, que retoma o conceito do Dicionário de Simbologia da noite como o tempo das gestaçôes, das germinações. O esquecimento ou a inconsciência constitui o cerne da definição da primeira noite em Blanchot. São exemplos dessa noite o sono e a morte ${ }^{14}$, pois, em ambos os estados, há a ausência de pensamento, de angústia e de sofrimento. Como pontua Blanchot, "tudo desaparece" nessa noite:

$\mathrm{Na}$ noite, tudo desapareceu. É a primeira noite. Aí se avizinham a ausência, o silêncio, o repouso, a noite. Aí, a morte se apaga o quadro de Alexandre, aí aquele que dorme não o sabe, aí se realiza e se cumpre a palavra em profundidade silenciosa que a garante como o seu sentido. ${ }^{15}$

A primeira noite é acolhedora. Novalis endereça-lhe seus hinos. Pode-se dizer dela: na noite, como se ela tivesse uma intimidade. Entra-se na noite e nela se repousa pelo sono e pela morte. ${ }^{16}$ 
A outra noite, em contraposição, não é o lugar do descanso, do acolhimento. Ela é essencialmente um estágio de perturbação, de inquietude, inacessível, não no sentido da impossibilidade de entrada, mas na incapacidade de saída; é a "lembrança sem repouso" ${ }^{17}$. Ela é um estado de consciência, de reflexão, em que o desaparecido torna a ter presença novamente:

Essa noite nunca é a noite pura. [...] Mas é a verdadeira noite, é noite sem verdade, a qual, entretanto, não mente, não é falsa, não é a confusão onde o sentido se desorienta, que não engana mas da qual não se pode corrigir os enganos. ${ }^{18}$

Nesse estado, é impossível corrigir os erros, os enganos, a consciência permanece latente, as angústias afloram. A morte não é uma possibilidade, tal como o sono; ambos pertencem à primeira noite. A primeira noite parece conter a verdade, o essencial, mas ao penetrá-la mais intimamente, buscando uma "intimidade mais profunda" ${ }^{19}$, adentra-se na outra noite. A outra noite possibilita o acesso a sua própria voz, ao eco dos seus passos na caminhada, "caminhada na direção do silêncio, mas o eco é-lhe devolvido como a imensidade sussurrante, rumo ao vazio, e o vazio é agora uma presença que vem ao seu encontro" ${ }^{\prime 2}$. Em tal estágio, há, portanto, uma consciência aguda das fragilidades e dos enganos, mas também há a incapacidade de comunicaçáo, descrita pela própria metáfora do eco do silêncio e, consequentemente, a presença do vazio.

A conceituação da outra noite blanchotiana descreve o ambiente em que o personagem d'Os Cus de Judas está inserido, ou seja, há uma impossibilidade de comunicação, de superação dos erros, mas há também um indício de relação com a primeira noite, pois o protagonista busca ser confortado, acolhido. Essa tentativa, no entanto, é frustrada. A noite completa, densa e ilimitada da África prolonga-se por Portugal, turvando o próprio dia e, por extensão metafórica, a própria vida de retornado. Nos planos narrativos concomitantes, África e Europa, a adjetivação da noite é caracterizada pela negatividade, retirando e subtraindo uma das características primordiais da noite que é a oferta do repouso, do sono e do sonho, conforme fica latente nos seguintes trechos da obra:

Eu estava farto da guerra, de me debruçar, até de madrugada, para camaradas que agonizavam, sob a lâmpada vertical da sala de operaçóes improvisada, farto do nosso sangue tâo cruelmente derramado, de sair para fora, a fumar um cigarro, ainda antes do dia, na completa noite escura que antecede o dia, na completa, densa, ilimitada noite escura que antecede o dia, e ver um súbito céu sereno e curvo povoado de desconhecidas estrelas, não o céu de alfazema e naftalina de Benfica, nem o duro céu de pinheiros de gra-
17. Ibidem.

18. Ibidem.

19.Ibidem, p. 169.

20. Idem. O espaço literário, 1987, p. 169. 
21.ANTUNES, António Lobo.

Os Cus de Judas, 2010, p. 150.

22. Ibidem, p. 33. nito da Beira, nem sequer o céu de tempestuosa água da Praia das Maçãs em que navegava ao acaso como um barco à deriva, mas o sereno e alto e inatingível céu de África e as suas constelaçóes que brilhavam, geométricas, à laia de pupilas irónicas. $^{21}$

As madrugadas, de resto, são o meu tormento, gordurosas, geladas, azedas, repletas de amargura e de rancor. Nada vive ainda e, todavia, uma ameaça indefinível ganha corpo, aproxima-se, persegue-nos, incha-nos no peito, impede-nos de respirar livremente, as pregas do travesseiro petrificamse, os móveis, agudos, hostilizam-nos. .22

No primeiro fragmento, a noite é a companhia do narrador naquela guerra do qual estava farto, confunde-se em um primeiro momento a própria guerra com o aspecto noturno pela incapacidade de escapar àquela realidade, tida como "densa, completa e ilimitada". O dia, a liberdade, é precedido pela noite, pela guerra, pela África. A dicotomia entre o dia-liberdade e a noite-guerra é reforçada na sequência pela enumeraçáo do céu em diferentes partes de Portugal: Benfica, Beira e Praia das Maçãs, lugares em que o narrador desejaria estar e não pode. Embora a caracterização de tais lugares ocorra por meio de adjetivaçóes negativas, a saber: "céu de alfazema e naftalina", "duro céu de pinheiros de granito" e "céu da tempestuosa água", elas compõem a geografia emotiva em que o narrador desejava estar inserido naquele momento, ele fala das estrelas conhecidas previamente, do seu espaço. A serenidade do céu, a iluminação das estrelas não tocava o solo africano, reside aí talvez a ironia vista pelas pupilas do narrador. Como um céu tão limpo, sereno, estrelado abarca uma realidade tão dura como a da guerra?

$\mathrm{O}$ primeiro fragmento dá conta da experiência da guerra e é nesse ambiente em que se dará a ressignificação da noite para o protagonista, processo que irá progredindo na volta ao continente europeu e culminará na madrugada em que há o encontro do narrador com sua interlocutora náo nomeada. No segundo fragmento, não há céu que aplaque a dor, o sofrimento, nem a lembrança de uma pátria distante como consolo. $\mathrm{O}$ regressado não consegue se reintegrar no mundo ao qual pertencia durante o dia, e tampouco à noite.

Ele procura preencher a madrugada, a solidão com companhias fortuitas, relaçôes sexuais e ingestáo de bebidas alcoólicas, esta última reconhecidamente um elemento de alteração química, que provoca euforia em um primeiro estágio. Ele faz uso dessas estratégias conscientemente, como fica evidente no seguinte fragmento:

O encanto dos bares, não é, consiste em, a partir das duas da manhã, não ser a alma a libertar-se do seu invólucro terrestre e a seguir verticalmente para o céu no esvoaçar mís- 
tico de cortinas brancas das mortes do missal, mas a carne que se livra, um pouco espantada, do espírito, e inicia uma dança pastosa de estátua de cera que se funde até terminar nas lágrimas de remorso da aurora, quando a primeira luz oblíqua nos revela, com implacabilidade radioscópica, o triste esqueleto da solidão sem remédio. ${ }^{23}$

O entorpecimento do álcool, disponível nos bares em que frequenta, é para o narrador uma fonte de inconsciência e um mecanismo de anulação, de separação da carne e do espírito que, inevitavelmente, termina na retomada da consciência quando o torpor se esvanece. A companhia feminina e as relaçóes sexuais compóem o outro mecanismo de resistência à incapacidade de lidar com a outra noite:

Inclusive o estar aqui consigo talvez não passe de um expediente de arame que me salve da maré-baixa de desespero que me ameaça, desespero de que não conheço a causa, percebe, e que à noite me enrola no visco do seu lodo, me afoga de aflição e receio, me molha o beiço de cima de um bigode de suor, me faz tremer os joelhos um contra o outro em castanholas de dentadura postiça de porteiro adormecido. ${ }^{24}$

Deixa que eu esqueça, olhando-a bem, o que não consigo esquecer, a violência assassina na terra prenhe de África, e tome-me dentro de você quando do redondo das minhas pupilas espantadas, enodoadas de vontade de si de que sou feito agora, surgirem as órbitas côncavas de fome das crianças da sanzala, perduradas do arame, a estenderem para os seus seios brancos, na manhã de Lisboa, as latas ferrugentas. ${ }^{25}$

As tentativas de não consciência, no entanto, são ineficazes, momentâneas, tal como a noite se transforma em manhã e o dia se transforma em noite em poucos minutos. O movimento de velar e desvelar proporcionado pelos mecanismos de fuga - álcool e relaçóes furtivas - corresponde ao acobertamento da noite e à iluminação proporcionada pela manhá.

Ambos, noite e manhã, são joguetes de que o narrador se vale para não enfrentar a sua dor, os seus fantasmas, a sua vida. A noite é uma tentativa frustrada de não ter consciência, da possibilidade de manter-se às escuras para o mundo. Temos, portanto, uma dicotomia na apreensão da noite, dado que ela é vista como um cobertor, que tenta impedir a manhã-consciência de chegar, numa tentativa similar ao dos deuses gregos, mas é inevitavelmente o espaço da reflexão, conforme apontado anteriormente, no Dicionário de Símbolos. A noite como todo símbolo representa um papel duplo.

De acordo com os conceitos blanchotianos, a primeira noite encoberta, aconchega; a outra noite desvela, revela. A narrativa "ainda que estrangulada" 26 de Lobo Antunes aponta essas duas interpretaçóes possíveis para a noite. $\mathrm{O}$ desejo de prolongar a noite e protelar o dia fica evidente na seguinte passagem:
23. Ibidem, p. 43.

24. Ibidem, p. 35.

25. Ibidem, p. 166.

26. GONDA, Gumercinda. O Santuário de Judas: Portugal entre a Existência e a Linguagem, 1988, p. 55. 
27. ANTUNES, António Lobo.

Os Cus de Judas, 2010, p. 126.

28. Ibidem, p. 135.

29. Ibidem.

30. Ibidem, p. 31.

31. Ibidem, p. 136.

32. Ibidem.

33. Ibidem, p. 137.
Cada vez mais fui prologando as madrugadas e encurtando os dias, na esperança de que uma noite perpétua me lançasse um pudico véu de sombra nas bochechas esverdeadas $[\ldots]^{27}$

Dessa forma, a noite no fragmento anterior dialogaria com a primeira noite, dado o seu caráter de proteção contra o dia, contra a vida exterior. No capítulo posterior, intitulado "R", o aspecto noturno em contraposição com o dia é visto como um espaço a ser abandonado, cujo desejo é a luz diurna, sua claridade. Aqui, a noite é a outra noite blanchotiana, "um labirinto de angústia", "uma noite sem fim, espessa, densa, desesperante"28.

Não chega, a manhã, não vai chegar nunca, é inútil esperar que os telhados empalideçam, uma lividez gelada aclare tremulamente os estores, pequenos cachos de criaturas transidas, brutalmente arrancadas ao útero do sono, se agrupem nas paragens do autocarro a caminho de um trabalho sem prazer: achamo-nos condenados, você e eu, a uma noite sem fim, espessa, densa, desesperante, desprovida de refúgios e saídas, um labirinto de angústia que o uísque ilumina de viés da sua claridade turva, segurando os copos vazios na mão como os peregrinos de Fátima as suas velas apagadas, sentados lado a lado no sofá, ocos de frases, de sentimentos, de vida, a sorrir um para o outro caretas de cães de faiança numa prateleira de sala, de olhos exaustos por semanas e semanas de apavoradas vigílias. ${ }^{29}$

A caminhada em direçáo ao silêncio de que nos fala Blanchot é a impossibilidade de comunicação estabelecida nesse estágio profundo de agonia. Os protagonistas estáo "ocos de frases, de sentimentos, de vida" ${ }^{30}$. Ele, narrador, destituído da crença do amor, da felicidade - nessa passagem tais valores se realizam na metáfora da manhã que não chega. Ela, cúmplice e ouvinte, na condenaçáo de ambos. A relaçáo estabelecida entre eles é baseada nas frustrações prévias, nas experiências acumuladas de fracasso, nesse não amor que compartilham, conforme aponta o médico:

já vivemos demais para correr o risco idiota de nos apaixonarmos, de vibrarmos nas tripas e na alma exaltaçóes de aventura, de nos demorarmos tardes a fio diante de uma porta fechada, de ramo de flores em riste, ridículos e tocantes, a engolir Cuspos aflitos de José Matias. ${ }^{31}$

Para eles, os amantes de uma noite só, o tempo trouxe a "sabedoria da incredulidade e do cinismo" 32 , a herança que o tempo legou a eles é a própria incapacidade de amar, dado que não há amor sem crença e sem entrega. $\mathrm{O}$ narrador aponta essa inaptidão ao afirmar que não suporta um "afecto sincero, incondicional, sem exigência de troca" ${ }^{33}$. No capítulo seguinte, intitulado "S", a primeira palavra é Sofia, da incapacidade de amar do 
capítulo anterior ao que foi talvez a única personagem feminina amada em plenitude pelo protagonista. Não à toa o trecho inicia com a imagem do despertar do protagonista em uma manhã:

Sofia, eu disse na sala, Volto já, e vim aqui, e sentei-me na sanita, diante do espelho onde todas as manhãs me barbeio, para falar contigo. [...] Sofia, aqui, aurora após aurora, quando ainda nenhuma manhá sublinha de verde os telhados, e as luzes se destacam, nítidas, no escuro, à laia de verrugas fosforescentes, quando a amplidão das trevas de Lisboa me envolve nas suas pregas apavorantes e moles, venho verter a medo na retrete uma urina furtiva de criança, empurrado pela mão enorme da mão que já não tenho. ${ }^{34}$

Sofia, angolana, morta e violentada pela Pide, é a imagem da mulher livre, risonha, apartada da guerra em que o narrador estava inserido. Sofia foi o sossego, foi o sono, foi a possibilidade de serenar em um outro corpo, em uma outra cor. Na passagem acima, a ambientação ocorre em um banheiro, na sanita, o que nos remete à condição de estar preso, estar fechado em um ambiente pequeno e sufocante. Em uma passagem nesse mesmo capítulo, o narrador faz alusão à metáfora de um peixe em um aquário de azulejos, a presença dos azulejos na descrição reforça a sensação de estar preso na própria pátria agora, dado que a arte da azulejaria faz parte intrinsecamente da cultura portuguesa. O narrador continua a se sentir confinado em seu próprio espaço, tal como esteve em Angola, no quartel; essa interpretação é reforçada pela própria estrutura do capítulo alternando os diferentes planos narrativos de forma concomitante. Temos, de um lado, a descrição do encontro com Sofia, como eles se conheceram, ambientado na África; de outro lado, a descrição da manhã do protagonista, ambientado em Portugal. A interlocutora aqui desaparece e seu papel é ocupado por Sofia.

A relaçáo estabelecida do narrador com ambas difere muito, pois com Sofia o relacionamento não fica restrito simplesmente ao ato físico, conforme fica insinuado com a interlocutora anônima, mas há também um envolvimento emocional, embora o narrador diga expressamente que a comunicação entre eles prescindia de palavras. A caracterizaçáo inicial da personagem é construída de forma a realçar a não vinculação com o conflito político e social de Angola, o que para o narrador funcionava como um ponto de refúgio; inclusive a descrição do primeiro ato sexual entre eles demonstra uma associaçáo com o protecionismo maternal envolvendo um menino e uma mulher mais velha:

e eu tinha certeza, Sofia, que sorrias no escuro o calado e misterioso riso das mulheres quando os homens se tornam de súbito meninos e se lhes entregam como filhos desprotegidos e frágeis, exaustos de lutarem dentro de si mesmos contra o que de si mesmos os revolta. ${ }^{35}$
34. Ibidem, p. 145.

35. Ibidem, p. 152. 
36. Ibidem, p. 156.

37. Ibidem, p. 172.
Ao descobrir que Sofia tinha sido levada pela Pide, o narrador busca informações sobre o paradeiro dela, mas ao ouvir a resposta do chefe da brigada, fica sem açáo, "sem a coragem de um grito de indignaçáo ou de revolta" ${ }^{36}$. A atitude do narrador perante as atrocidades da guerra de isenção e de covardia transformam-no em um ser humano repulsivo para si próprio. Vive-se a atrocidade da guerra, teme-se a própria sobrevivência, anseia rever a filha e a esposa, nada faz a não ser esperar que tudo passe o mais rápido depressa. Para lidar, precisou não sentir, abdicar dos seus valores, fechou os olhos para situaçóes abjetas em prol da sobrevivência. Os olhos fechados durante a guerra, no entanto, reabrem à noite e o conduzem à eterna noite, da qual só poderá sair pela manhã.

Conforme apontamos anteriormente, os deuses gregos manipulavam a duração do dia e da noite como desejavam. $\mathrm{O}$ narrador antuniano, entretanto, não possui meios de alterar a duração do dia e da noite. Era inevitável que a manhã insinuasse seus primeiros sons e cores:

Vai começar a amanhecer e todos os candeeiros se tornarão inúteis, o sol exibirá sem piedade os nossos corpos deitados, as rugas, as pregas tristes da boca, o cabelo emaranhado, os restos de pintura e de creme na almofada. [...] A energia musculosa do dia empurra-nos, como às corujas, para as derradeiras pregas da sombra, onde agitamos as penas húmidas numa ansiedade inquieta, encolhidos um contra o outro à procura de proteção que não há. Porque ninguém nos salva, ninguém pode mais salvar-nos, nenhuma companhia virá, de morteiro em punho, ao nosso encontro. Eis-nos irremediavelmente sós no convés desta cama sem bússola, baloiçando pela alcatifa do quarto hesitaçóes de jangada. ${ }^{37}$

A sensação de acobertamento, proporcionada pela noite, pelo estado de obscuridade e pela capacidade de velar termina à medida que amanhece e o sol proporciona a luz reveladora. Não há companhia feminina que o salve, nem álcool para alterar as percepçôes. Ninguém pode salvar o narrador, porque a salvaçáo dele não está no outro, nem em determinada situação. A salvação dele é adentrar no dia, encarar a luminosidade da vida, deixar a outra noite e a presença do vazio como símbolos do seu passado. Desibernar dessa noite perpétua e experimentar $a$ primeira noite, o sono e a vida, encarando a noite como símbolo que é, a um só tempo, o abrigo das trevas e o da preparação para o dia, de onde advém a luz. Estabelecer entre o dia e a noite um movimento dialético, do velamento ao desvelamento, da obscuridade à luz, fazendo do dia a totalidade do dia e da noite.

Para Blanchot, a primeira noite é ainda um prolongamento do dia. A noite é o encerramento do dia e o seu começo 
também. O espaço reservado ao trabalho, às criaçooes é o dia notoriamente, inclusive, as profissōes exercidas no ambiente noturno, mesmo que honestamente, levam suspeitas quanto a sua legitimidade.

À medida que o dia se prolonga, o elemento noturno fica restringido, incerto ou, quando a situação é inversa, a noite é prolongada demasiadamente, o dia perde sua força inicial. A justa medida entre esses dois elementos foi apontada por Blanchot:

É um risco essencial, é uma das decisões possíveis do dia. Existem várias: ou acolher a noite como o limite do que não deve ser transposto; a noite é aceita e reconhecida, mas somente como limite e como a necessidade de um limite: não se deve ir além. Assim fala a medida grega. Ou então a noite é o que o dia, em última instância deve dissipar: o dia trabalha sob a influência exclusiva do dia, é conquista e labor de si mesmo [...]. Ou então a noite é o que o dia não quer somente dissipar mas do que quer apropriar-se: a noite é também o essencial que não se deve perder mas conservar, acolher não mais como limite em si mesma; no dia deve passar a noite; a noite que se faz dia torna a luz mais rica e faz da claridade, em vez da cintilação da superfície, a irradiação oriunda da profundidade. O dia é então a totalidade do dia e da noite, a grande promessa do movimento dialético. ${ }^{38}$

O que não há na narrativa antuniana é movimento dialético, a justa medida entre o dia e a noite. Dessa forma, o equilíbrio fica afetado e o surgimento da outra noite acaba por dominar por completo o narrador.

Morrer e dormir são dois conceitos de Blanchot ligados à primeira noite. De acordo com o teórico francês, os dois são entre-limites, um momento de consumação entre o dia e $a$ noite. A morte para Blanchot é um ir "ao encontro da liberdade que torna livre o $\operatorname{ser}^{39}$ ", no entanto, ela representa a agonia e a frustração quando a morte ocorre só, isto é, quando todos ao redor já faleceram, nas palavras de Blanchot:

Morre só porque não morre agora, onde nós estamos, mas no futuro e no ponto extremo do futuro, desligado não só de sua existência presente mas também de sua morte presente: morre só porque morrem todos, e isso também gera uma grande solidão. Para aqueles que ficam e cercam o agonizante, ela chega como uma morte a morrer cada vez mais, que repousa neles, que eles devem preservar, prolongar até ao instante em que, encerrados os tempos, cada um morrerá alegremente - todos juntos. Cada um está, neste sentido, em agonia até ao fim do mundo. ${ }^{40}$

O trecho acima estabelece uma relação com a realidade da guerra, vivenciada pelo narrador em $O s$ Cus de Judas, uma vez
38. BLANCHOT, Maurice.

O espaço literário, 1987, p. 167-168.

39. Ibidem, p. 164.

40. Ibidem, p. 165. 
41. ANTUNES, António Lobo

Os Cus de Judas, 2010, p. 65.

42. BLANCHOT, Maurice.

O espaço literário, 1987, p. 266. que a essência individual de uma guerra é a sobrevivência em meio à degradação física. Ao narrar as mortes dos companheiros em Angola, o narrador abarca também um pouco a sua própria morte, morte sobrevivida, morte sobre a vida. A vivência dessa experiência como médico acentua ainda mais o caráter da morte em vida de que nos fala Blanchot. Vivenciar a morte de companheiros e colegas no quartel foi uma morte, o narrador morreu "só, porque morrem todos". Em alguns momentos da narração, o protagonista revela o desejo de ter escolhido uma outra profissão para que não tivesse de estar ali, naquela guerra, rodeado pelo sangue, pela morte, pelo cheiro de morte, que o acompanha mesmo após o seu retorno.

A experiência de vivenciar as mortes alheias e, em decorrência disso, um pouco a sua própria, projeta no sobrevivente uma sensação de solidão extremada e um estado de agonia permanente, segundo Blanchot. $\mathrm{O}$ narrador antuniano reflete essa caracterização, à medida que não consegue estabelecer relacionamentos, nem diálogos, numa permanente sensação de medo e busca por refúgio.

Nem o sono é refúgio para o narrador cuja impossibilidade de adormecer é mencionada explicitamente no capítulo "I":

Há quanto tempo não consigo dormir? [...] Há quanto tempo de facto não consigo dormir? Se fecho os olhos, uma rumorosa constelação de pombos levanta voo dos telhados das minhas pálpebras descidas, vermelhas de conjuntivite e de cansaço ${ }^{41}$

Para Blanchot, dormir é um ato de entrega, uma comunhão com o mundo, um pacto, que fica interdito para o médico português, dado que ele não consegue se desvencilhar da outra noite. Há uma relação sincrônica entre o ato de dormir e o dia/manhã. À medida que o sono guarda em si a possibilidade de mudança não perceptível. Dorme-se à noite e desperta-se num outro dia, já amanhecido, já novo.

Dormir é a ação clara que nos promete ao dia. Dormir, eis o ato extraordinário de nossa vigilância. Dormir profundamente só nos faz escapar ao que existe no fundo do sono. Onde está a noite? Não há mais noite. ${ }^{42}$

A noite desaparece no ato de dormir e é justamente o oposto do que ocorre na narrativa de Lobo Antunes. Nada parece desaparecer, nada parece salvá-lo. Dormir seria a possibilidade de estar desatento ao que ocorre ou ocorreu e, portanto, ela não é permitida ao narrador. A noite é seguida pela manhã, sem sono, sem espaço de comunhão.

Depois de tantos amores e de tantas noites, a manhã-consciência chega e é na figura de Isabel que o narrador se ampara. 
Ele sai da outra noite inicialmente, para adentrar na primeira noite e chegar ao dia:

Pode apagar a luz: já não preciso dela. Quando penso na Isabel cesso de ter receio do escuro, uma claridade ambarina reveste os objetos da serenidade cúmplice das manhãs de julho, que se me afiguraram sempre disporem de mim, com o seu sol infantil, os materiais necessários para construir algo de inefavelmente agradável que eu não lograria jamais elucidar. ${ }^{43}$

Ao pensar em Isabel, o narrador é dotado de coragem para enfrentar o seu passado, afastando os fantasmas da guerra, as agruras da sua consciência, a agonia guardada. Do relacionamento anterior à guerra, emerge a imagem daquela mulher que o conduz novamente ao dia, expurgando-o da noite eterna, nas palavras do narrador: "A Isabel que substituía aos meus sonhos paralisados o seu pragmatismo docemente implacável, consertava as fissuras da minha existência com o rápido arame de duas ou três decisões de que a simplicidade me assombrava ${ }^{44}$."

No entanto, ao avançar do relato e, consequentemente do capítulo "X", a euforia da imagem de Isabel dá lugar às lembranças do relacionamento do casal, das expectativas frustradas, da impossibilidade de estarem juntos, dos erros cometidos. A mudança de tom do personagem no decorrer do capítulo fica visível se analisarmos a sua relação com a luz do quarto, ora ele pede para deixar acesa, ora solicita que apague.

No trecho anteriormente citado, o narrador manifesta claramente o desejo que a luz seja apagada e alega não precisar mais dela, pois a figura de Isabel atenua suas angústias e imprime a ele coragem. Em seguida, a mesma frase abre o parágrafo seguinte: "Pode apagar a luz: talvez não fique tão sozinho como isso neste quarto enorme, talvez que a Isabel ou você voltem um dia destes a visitar-me, eu oiça a voz ao telefone, a voz miudamente precisa pelos furos do baquelite do telefone" ${ }^{45}$. Aqui, o narrador permanece dotado da vontade de encarar a realidade, confirmada pelo desejo de manter a luz apagada, isto é, de enfrentar seus medos, sua consciência, apoiado na ideia de um amor possível, quer de Isabel, quer da interlocutora.

Ainda no mesmo parágrafo, o narrador muda de opinião sobre a luz do quarto e solicita à interlocutora que não apague a luz, numa estrutura frasal semelhante às dos parágrafos anteriores:

Reflectindo melhor, não apague a luz: quem sabe se esta manhã oculta dentro de si uma noite mais opaca do que todas as noites que até agora atravessei, a que vive no fundo das garrafas de uísque, das camas desfeitas e dos objetos de ausência, uma noite com um cubo de gelo à superfície, três dedos de líquido amarelo por baixo, e um silêncio insupor-
43. ANTUNES, António Lobo.

Os Cus de Judas, 2010, p. 185.

44. Ibidem, p. 185.

45. Ibidem, p. 186. 
46. Ibidem, p. 187.

47. Ibidem.

48. GONDA, Gumercinda. O Santuário de Judas: Portugal entre a Existência e a Linguagem, 1988, p. 47. tável no interior vazio, uma noite em que me perco, a tropeçar de parede a parede, tonto de álcool, falando comigo o discurso da solidão grandiosa dos bêbados, para quem o mundo é um reflexo de gigantes contra os quais, inutilmente, se encrespam. ${ }^{46}$

A possibilidade da solidão o afeta de tal modo que ele prefere permanecer com a luz a fazer companhia, a velar pelo seu sono impossível, na tentativa de adormecimento, na tentativa de inconsciência. A reflexão conduz o narrador a não querer ficar sozinho e, a na ausência de uma companhia feminina, a luz ocupa o espaço, impede a noite opaca. Ao se distanciar da figura de Isabel pela rememoração do passado e da sua interlocutora pelo avançar da hora, o personagem-narrador decide definitivamente não apagar a luz:

Não apague a luz: quando você sair a casa aumentará inevitavelmente de tamanho, transformando-se numa espécie de piscina sem água em que os sons se ampliam e ecoam, agressivos, retesos, enormes, batendo-me violentamente contra o corpo como as marés do equinócio na muralha da praia, rolando sobre mim espumas foscas de sílabas. ${ }^{47}$

Há, claramente, na passagem, um desejo manifestado do interlocutor de não ficar sozinho, a opressão da casa vazia, dos sons da casa vazia, são metaforizados na imagem das marés contra uma muralha, no som contínuo e violento, na força destruidora e inevitável das ondas. Dentro dessa análise, o narrador só pode emergir da outra noite em que se encontra, da solidão que o paralisa por meio da possibilidade de uma relação afetiva.

Seria apenas pelo amor que ele conseguiria reestabelecer a vontade de enfrentar o dia, a manhã. Não apenas o amor de uma relação conjugal, mas o amor pela literatura, pela aventura da escrita. A literatura, assim como o amor, podem ser os responsáveis por manter o interlocutor a salvo da noite perpétua. $\mathrm{O}$ amor até então é fracassado, inacessível; a literatura fragmentada, estilhaçada, mas ela é meio pelo qual sobrevive o narrador para contar. Sobre esse aspecto, Gumercinda Gonda aponta:

A escrita se transforma na aventura de se viver daquilo que se rememora, sem que isto concilie o autor com a vida, pois escrever torna-se a caricatura de um projeto que ele reconhece por princípio no momento de construir o romance, e até mesmo antes, como insuficiente e inacessível. É por aí que avança o território da angústia, que leva o escritor, esquartejado por uma realidade tão dura, quanto ágil, a encontrar-se de novo, mágico ou artista, retomando o estilhaçado jogo de armar, cujo resultado final pode-lhe apontar, mais uma vez, para a essência e para a verdade. ${ }^{48}$ 
Retomando o estilhaçado jogo, o protagonista termina o relato, no capitulo "Z", reforçando o caráter de realidade das ações cotidianas. Em direção ao dia, a manhã tinge os objetos, as paredes com a luz e a consciência da vida hodierna: o emprego, a revisão do carro, a consulta do dentista. Algumas certezas metereológicas: o céu cor-de-rosa e o tempo quente. A realidade instituída na sociedade portuguesa como verdadeira e segura. A guerra colonial não existiu, nem a PIDE, nem Angola, nem o fascismo, nem a outra noite. $\mathrm{O}$ sol invade a narrativa como a ofuscar o negrume - da noite e da consciência. 


\section{Referências}

ANTUNES, António Lobo. Os Cus de Judas. 2a ${ }^{\mathrm{a}}$ ed. Rio de Janeiro: Objetiva, 2010.

2007

Segundo livro de crônicas. Lisboa: Dom Quixote,

BLANCHOT, Maurice. O espaço literário. Tradução Álvaro

Cabral. Rio de Janeiro: Rocco, 1987.

O livro por vir. Tradução Leyla Perrone-Moisés. São

Paulo: Martins Fontes, 2005.

CHEVALIER, Jean \& GHEERBRANT, Alain. Dicionário de simbolos. Tradução Vera da Costa e Silva. Rio de Janeiro: José Olympio, 1997.

FARIA, Ângela Beatriz de Carvalho. "Arquipélagos da insônia brilham no escuro na ficção de António Lobo Antunes". $O$ Marrare - revista de pós-graduação em literatura portuguesa da UERJ. n. 12, p. 33-46, 2010. Disponível em: http://www. omarrare.uerj.br/numero12/pdfs/angela.pdf.

"A noite escura da alma". Jornal do Brasil, Rio de Janeiro, 6 set. 2003, Caderno de Ideias, p. 6.

GONDA, Gumercinda Nascimento. O Santuário de Judas: Portugal entre a Existência e a Linguagem. Dissertação (Mestrado em Literatura Portuguesa) - Faculdade de Letras, Universidade Federal do Rio de Janeiro, Rio de Janeiro, 1988.

HOUAISS, António; VILLAR, Mauro de Salles. Dicionário Houaiss da Lingua Portuguesa. Rio de Janeiro: Objetiva, 2001.

HUTCHEON, Linda. Poética do pós-modernismo. Tradução Ricardo Cruz. Rio de Janeiro: Imago, 1991.

REIS, Carlos; LOPES, Ana Cristina M. Dicionário de Narratologia. Coimbra: Almedina, 2007.

RIBEIRO, Margarida Calafate. "Os Cus de Judas, de António Lobo Antunes: dos tristes trópicos à feira cabisbaixa”. In: Uma história de regressos. Porto: Ediçôes

Afrontamento, 2004.

SEIXO, Maria Alzira. "Pós-colonialismo". In: Os romances de Lobo Antunes. Lisboa: Publicaçóes Dom Quixote, 2002.

(org.). Dicionário da obra de António Lobo Antunes.

Volume II. Lisboa: Imprensa Nacional - Casa da Moeda, 2008. 
SELIGMANN-SILVA, Márcio (org.). História, Memória,

Literatura. O testemunho na Era das Catástrofes. Campinas: Ed.

Unicamp, 2003. 
